OPEN ACCESS

Edited by:

Giovanna Suzzi,

Università degli Studi di Teramo, Italy

Reviewed by:

Koshy Philip,

University of Malaya, Malaysia

Giorgia Perpetuini,

Università degli Studi di Teramo, Italy

${ }^{*}$ Correspondence:

Carolina Gutiérrez-Cortés

cgutierrezco@unal.edu.co

Specialty section:

This article was submitted to

Food Microbiology,

a section of the journal

Frontiers in Microbiology

Received: 10 May 2018 Accepted: 16 November 2018 Published: 03 December 2018

Citation:

Gutiérrez-Cortés $C$, Suarez $H$, Buitrago G, Nero LA and Todorov SD (2018) Enhanced Bacteriocin

Production by Pediococcus pentosaceus 147 in Co-culture With Lactobacillus plantarum LE27 on

Cheese Whey Broth.

Front. Microbiol. 9:2952.

doi: 10.3389/fmicb.2018.02952

\section{Enhanced Bacteriocin Production by Pediococcus pentosaceus 147 in Co-culture With Lactobacillus plantarum LE27 on Cheese Whey Broth}

\author{
Carolina Gutiérrez-Cortés ${ }^{*}$, Héctor Suarez¹, Gustavo Buitrago², Luis Augusto Nero ${ }^{3}$ \\ and Svetoslav Dimitrov Todorov ${ }^{3}$ \\ ${ }^{1}$ Instituto de Ciencia y Tecnología de Alimentos, Facultad de Ciencias Agrarias, Universidad Nacional de Colombia, Bogotá, \\ Colombia, ${ }^{2}$ Instituto de Biotecnología, Facultad de Ciencias, Universidad Nacional de Colombia, Bogotá, Colombia, \\ ${ }^{3}$ Departamento de Veterinária, Universidade Federal de Viçosa, Viçosa, Brazil
}

The production of bacteriocins by lactic acid bacteria $(\angle A B)$ has been of wide interest in the food industry due to their potential application in biopreservation. The production of bacteriocins is usually low in single strain fermentation, but can improve when the bacteriocinogenic strain is cultured in association with another bacteria. The present work aims to evaluate the growth and production of bacteriocins by Pediococcus pentosaceus 147 (bacteriocinogenic strain) in co-culture with Lactobacillus plantarum LE27 (inducer strain) using a culture medium based on cheese whey (CW). Strains were inoculated in co-culture in a CW broth at 7.24 Log CFU/mL of initial concentration of P. pentosaceus 147 and incubated at $37^{\circ} \mathrm{C}$. Bacteriocin production was measured after $24 \mathrm{~h}$ by the critical dilution method, biomass was measured by plating on MRS agar ( $1 \%$ aniline blue), and a mono-culture was used as a control. The titers of bacteriocins produced by $P$. pentosaceus 147 in mono-culture were 19,200 AU/mL lower than those obtained in co-culture with $L b$. plantarum LE27 at 51,200 AU/mL. The effect of adding the inducer strain at different times of incubation $(3,6,9$, and $12 \mathrm{~h}$ ) was evaluated, with the addition of the induction factor at the beginning of the incubation of $P$. pentosaceus 147 generating the highest bacteriocin activity. This study shows the potential of inducing bacteriocinogenesis using co-cultures of strains of the genera Pediococcus and Lactobacillus and using alternative substrates such as cheese whey.

Keywords: bacteriocins, acid lactic bacteria, biopreservation, co-culture, cheese whey

\section{INTRODUCTION}

Bacteriocins are proteinaceous antimicrobial substances produced by Gram positive and Gram negative bacteria, with antagonistic activity against other, normally closely related, bacterial species (Taniguchi and Tanaka, 2004; Beshkova and Frengova, 2012). These substances are classified according to their molecular size, specificity of mode of action, presence of modified amino acids and morphological traits into four classes 
(Beshkova and Frengova, 2012; Zacharof and Lovitt, 2012). Bacteriocinogenic Pediococcus strains usually produce pediocin $\mathrm{PA}-1 / \mathrm{AcH}$, a class IIa bacteriocin encoded by an operon composed of structural genes in addition to pedB (encodes the immunity peptide that protects the producer strain), pedC (codifies the $\mathrm{ABC}$ transporter), and pedD (codifies the complementary peptide to extracellular translocation) (Papagianni and Anastasiadou, 2009; Oppegard et al., 2015; Mesa-Pereira et al., 2017). The structure of this operon is similar to that described for plantaricins produced by Lactobacillus plantarum C11 (Diep et al., 1996) and Lb. plantarum NC8 (Maldonado et al., 2004), indicating that PA-1/AcH production can be modulated in the same way. Thus, pediocin production can be increased when the producer strain is co-cultured with other strains as reported by several authors (Maldonado et al., 2003; Bader et al., 2010; Man et al., 2012; Chanos and Mygind, 2016; Maldonado-Barragán et al., 2016).

Many investigations have been focused on the induction of bacteriocin production by the presence of another strain in the culture medium mediated by the quorum sensing system (QS), which is based on genetic expression synchronization (Chang et al., 2007; Ng and Bassler, 2009) to produce useful metabolites such as bacteriocins (Williams and Cámara, 2009; Pereira et al., 2013; Komnatnyy et al., 2014; Jia et al., 2017). The presence of additional bacteria in co-culture acts as a stress signal, and usually enhances the production of bacteriocin. Some studies have demonstrated that Lactobacillus spp. can act as an inductor improving the bacteriocin production of Lactococcus lactis and Lb. plantarum strains (Maldonado et al., 2004; RojoBezares et al., 2007; Kos et al., 2011; Maldonado-Barragán et al., 2013). These studies have supported the concept of coculture by which two or more strains are inoculated under aseptic conditions to obtain a metabolite of interest. These systems generate cell-to-cell interactions allowing stimulation of the production and expression of metabolites with industrial, medical and environmental applications (Goers et al., 2014). This has been previously shown in experiments with Lactobacillus strains; however, co-culture systems have not been evaluated on strains belonging to the genus Pediococcus sp. Based on the fact that plantaricin and pediocin are both encoded by similar operons, it will be possible to suggest that the co-culture system might be used to increase the bacteriocin production and expression by Pediococcus pentosaceus 147 [isolated form minas cheese and characterized as pediocin producer (GutiérrezCortés et al., 2018)] as reported for Lactobacillus spp. cultures. This improvement in bacteriocin production might allow the development of an industrial production with applications on food preservation.

On the other hand, it is known that bacteriocin production by LAB (lactic acid bacteria) is highly affected by culture conditions as well as culture media composition (Todorov and Dicks, 2004; Sridevi et al., 2017), which must contain carbohydrates, organic nitrogen sources, amino acids, proteins, minerals and vitamins (De Arauz et al., 2012). Different studies have focused on the design of a new medium due to the high cost of the MRS broth in order to reduce the cost of bacteriocins production (Guerra et al., 2001; Liu et al., 2005; Kumar et al., 2012; Kaur et al., 2013;
Suganthi and Mohanasrinivasan, 2015; Hati et al., 2017). In the last decade, research on bacteriocin production has focused on the development of simpler (and lower cost) culture media obtained from different natural sources such as molasses, corn syrup (Todorov and Dicks, 2006a,b), soy milk (Wolf-Hall et al., 2009), and cheese whey (CW) (Liu et al., 2005; Kumar et al., 2012; Prazeres et al., 2012; Hati et al., 2017) in order to obtain high amounts of bacteriocins with minimal cost and minimal usage of industrial waste products. CW is a highly nutritional matrix, containing more than half of the solids present in milk, with $6-10 \mathrm{~g} / \mathrm{L}$ of proteins, $46-52 \mathrm{~g} / \mathrm{L}$ of lactose, and minerals (Conti et al., 2012). Additionally, CW contains soluble vitamins and some enzymes that may be of interest to different industries (Prazeres et al., 2012), i.e., as raw material for biotechnological processes or for obtaining metabolites from bacterial growth (Sánchez et al., 2009). According to the literature, co-culture systems have been performed on commercial media MRS; therefore, the utilization of $\mathrm{CW}$ in the co-culture of $\mathrm{LAB}$ can be considered as a novel application of this kind of developed medium.

In the present study, a co-culture system was assessed in order to increase the bacteriocin production by $P$. pentosaceus 147 using $L b$. plantarum LE27 as inductor strain. CW was also used as an alternative matrix for growth and bacteriocin production. The results confirm that induction by competition is applicable to Pediococcus strains and that $\mathrm{CW}$ is an optimal substrate for bacteriocin production in co-culture.

\section{MATERIALS AND METHODS}

\section{Bacterial Strains and Culture Media}

Pediococcus pentosaceus 147 was previously isolated from artisanal Minas cheese produced with raw milk, and characterized as a bacteriocinogenic strain with inhibitory activity against different strains of Listeria spp. (Gutiérrez-Cortés et al., 2018) of 51,200 AU/mL when cultured in MRS broth (Oxoid, Basingstoke, England). The sugar fermentation profile of P. pentosaceus 147 was assessed by using API50CHL (bioMérieux, Marcy-l'Étoile, France) according to the manufacturer's instructions. $\mathrm{Lb}$. plantarum LE27 was previously isolated from molasses (Amortegui et al., 2014). L. monocytogenes 104 was previously isolated from poultry (Chiarini, 2007). LAB strains were stored in MRS broth and L. monocytogenes in brain, heart, and infusion (BHI, Oxoid), both supplemented with $20 \%$ glycerol $(\mathrm{v} / \mathrm{v})$ at $-20^{\circ} \mathrm{C}$. Before using aliquots of the stock, cultures were transferred to appropriate broths and incubated at $37^{\circ} \mathrm{C}$ for $24 \mathrm{~h}$.

Cheese whey-based culture media were developed by using CW (CIMPA S.A.S., Bogotá, Colombia) and other compounds as described in Table 1. MRS broth (Oxoid) was considered as a control for bacterial growth and bacteriocin production.

\section{Antimicrobial Activity of $P$. pentosaceus 147}

The overnight culture of $P$. pentosaceus 147 was diluted until an approximate concentration of $10^{7} \mathrm{CFU} / \mathrm{mL}$ was 
TABLE 1 | Composition of culture media developed for bacterial growth and bacteriocin production by $P$. pentosaceus 147 and Lb. plantarum LE27 (g/L).

\begin{tabular}{lcc}
\hline Compound $^{\mathbf{1}}$ & $\begin{array}{c}\text { Modified MRS } \\
(\mathbf{g} / \mathbf{L})\end{array}$ & $\begin{array}{c}\text { Cheese whey } \\
\text { (CW) (g/L) }\end{array}$ \\
\hline Peptone & 10 & 19.8 \\
Yeast extract & 8 & 8 \\
Meat extract & 4 & 16 \\
Whey $^{2}$ & 20 & 30 \\
$\mathrm{~K}_{2} \mathrm{HPO}_{4}$ & 2 & 0.5 \\
Tween $^{80}$ & 1 & 2 \\
Ammonium citrate & 2 & 2 \\
Sodium acetate & 5 & 1.5 \\
MgSO $_{4}$ & 0.2 & 0.2 \\
$\mathrm{MnSO}_{4}$ & 0.04 & 0.04
\end{tabular}

${ }^{1}$ All compounds, except whey, from Sigma-Aldrich (St. Louis, MI, United States); ${ }^{2}$ Cheese whey obtained from CIMPA S.A.S. (Bogotá, Colombia), with the following characteristics: humidity $43 \mathrm{~g} / \mathrm{Kg}$, ash $70.8 \mathrm{~g} / \mathrm{Kg}$, lactose $648.2 \mathrm{~g} / \mathrm{Kg}$, proteins $103 \mathrm{~g} / \mathrm{Kg}$, and fat $28.2 \mathrm{~g} / \mathrm{Kg}$; sodium $8183 \mathrm{mg} / \mathrm{Kg}$, potassium $7484,5 \mathrm{mg} / \mathrm{Kg}$, calcium $13116 \mathrm{mg} / \mathrm{Kg}$, and magnesium $625.5 \mathrm{mg} / \mathrm{Kg}$. Before use, $\mathrm{pH}$ of culture media was adjusted to 6.5 and autoclaved at $120^{\circ} \mathrm{C}$ for $15 \mathrm{~min}$.

reached, and transferred individually to MRS (Oxoid) and modified MRS (Table 1), followed by incubation at $37^{\circ} \mathrm{C}$ for $24 \mathrm{~h}$. Then, cultures were centrifuged at $8,000 \times g$, and the $\mathrm{pH}$ of the cell free supernatant (CFS) was adjusted to 6.5. The treated CFS was twofold diluted up to 1:256, and aliquots of $10 \mu \mathrm{L}$ were spotted on a surface of a BHI medium with $1 \%$ agar (Oxoid), which was previously prepared and inoculated with L. monocytogenes 104 at $10^{6} \mathrm{CFU} / \mathrm{mL}$. Inhibitory activity was expressed as arbitrary units $/ \mathrm{mL}(\mathrm{AU} / \mathrm{mL})$, considering the inverse of the highest dilution that presented an inhibitory zone higher than $2 \mathrm{~mm}$ in diameter (Gutiérrez-Cortés et al., 2018).

\section{Growth Dynamics and Bacteriocin Production on CW Broth on Mono-Culture}

Pediococcus pentosaceus 147 and Lb. plantarum LE27 cultures were individually transferred to MRS and CW broth, at the end concentration of $10^{6} \mathrm{CFU} / \mathrm{mL}$, and incubated at $37^{\circ} \mathrm{C}$ for $24 \mathrm{~h}$. Every $3 \mathrm{~h}$, aliquots of cultures were obtained, 10fold diluted in $\mathrm{NaCl} 0.85(\mathrm{w} / \mathrm{v})$ and plated in duplicates on MRS agar, followed by incubation at $37^{\circ} \mathrm{C}$ for $24 \mathrm{~h}$ and with the results being expressed as $\mathrm{CFU} / \mathrm{mL}$. Aliquots were also treated as described previously to obtain CFS and tested for antimicrobial activity against L. monocytogenes 104, as described above. Tests were performed in three independent repetitions.

In addition, $P$. pentosaceus 147 was inoculated at final concentrations of $10^{5}$ and $10^{6} \mathrm{CFU} / \mathrm{mL}$ only on $\mathrm{CW}$ broth, and incubated at $37^{\circ} \mathrm{C}$ for $24 \mathrm{~h}$. Bacterial growth and bacteriocin production were assessed every $3 \mathrm{~h}$, as described above, in three independent repetitions.

\section{Growth Dynamics and Bacteriocin Production of $P$. pentosaceus 147 and $L b$. plantarum LE27 Co-culture in CW Broth}

Growth and inhibitory activity were measured in a coculture of $P$. pentosaceus 147 and Lb. plantarum LE27 as described before. Strains were co-inoculated in CW at different concentration combinations (1: both at $10^{6} \mathrm{CFU} / \mathrm{mL}$, and 2: $P$. pentosaceus 147 at $10^{6} \mathrm{CFU} / \mathrm{mL}$ and $L b$. plantarum $\mathrm{LE} 27$ at $10^{5} \mathrm{CFU} / \mathrm{mL}$ ) and incubated at $37^{\circ} \mathrm{C}$ for $24 \mathrm{~h}$. Aliquots were obtained every $3 \mathrm{~h}$, and CFS were prepared and tested for inhibitory activity against L. monocytogenes 104, as described above. Also, aliquots were 10-fold diluted in $\mathrm{NaCl} 0.85 \%(\mathrm{w} / \mathrm{v})$, surface plated on MRS agar (Oxoid) supplemented with aniline blue $(0.1 \%$, w/v) (Brauman et al., 1996), and incubated at $37^{\circ} \mathrm{C}$ for $24 \mathrm{~h}$. Colonies were enumerated considering their color (light blue for $P$. pentosaceus 147, and dark blue for Lb. plantarum LE27), and final results were expressed as CFU/mL. Tests were conducted in three independent repetitions.

\section{Adding of Lb. plantarum LE27 at Different Times as Pulses of Induction in the Bacteriocin Production by $P$. pentosaceus 147}

Bacteriocin production of $P$. pentosaceus 147 was measured considering different co-inoculation periods and frequencies with Lb. plantarum LE27. Flasks containing $75 \mathrm{~mL}$ of $\mathrm{CW}$ were inoculated with $1.5 \mathrm{~mL}$ of $P$. pentosaceus 147 at an approximate final concentration of $10^{6} \mathrm{CFU} / \mathrm{mL}$, being incubated at $37^{\circ} \mathrm{C}$ for $24 \mathrm{~h}$. In different frequencies and times, aliquots of $1.5 \mathrm{~mL}$ of a $L$ b. plantarum LE27 culture $\left(10^{5} \mathrm{CFU} / \mathrm{mL}\right)$ were added in the P. pentosaceus $147 \mathrm{CW}$ systems (Table 2). After $24 \mathrm{~h}$, the CFS of resulting cultures was obtained as described before, and the inhibitory activity against $L$. monocytogenes 104 was evaluated as described above. The experiment was conducted in three independent repetitions.

TABLE 2 | Scheme of the inoculation (x) of Lb. plantarum LE27 and $P$. pentosaceus 147 in CW systems at different times and frequencies.

\begin{tabular}{|c|c|c|c|c|c|}
\hline \multirow[t]{2}{*}{ Treatment } & \multirow{2}{*}{$\begin{array}{c}\text { P. pentosaceus } 147 \\
\mathrm{Oh}\end{array}$} & \multicolumn{4}{|c|}{ Lb. plantarum LE27 } \\
\hline & & $3 \mathrm{~h}$ & $6 \mathrm{~h}$ & $9 \mathrm{~h}$ & $12 \mathrm{~h}$ \\
\hline $1(\mathrm{~A})$ & $x$ & $x$ & - & - & - \\
\hline 2 (B) & $x$ & - & $x$ & - & - \\
\hline $3(\mathrm{C})$ & $x$ & - & - & $x$ & - \\
\hline $4(\mathrm{D})$ & $x$ & - & - & - & $x$ \\
\hline 5 (E) & $x$ & $x$ & $x$ & - & - \\
\hline $6(F)$ & $x$ & - & $x$ & $x$ & - \\
\hline $7(\mathrm{G})$ & $x$ & - & - & $x$ & $x$ \\
\hline $8(\mathrm{H})$ & $x$ & $x$ & $x$ & $x$ & - \\
\hline $9(\mathrm{l})$ & $x$ & - & $x$ & $x$ & $x$ \\
\hline $10(\mathrm{~J})$ & $x$ & - & $x$ & $x$ & $x$ \\
\hline 11 (control) & $x$ & - & - & - & - \\
\hline
\end{tabular}




\section{Data Analysis}

Antimicrobial activity $(\mathrm{AU} / \mathrm{mL})$ and microbial counts (log $\mathrm{CFU} / \mathrm{mL}$ ) were compared considering the tested conditions in the different assays, as described previously, by Analysis of Variance (ANOVA) and the Tukey test, using the software ( $\mathrm{R}$ Core Team, 2015) and considering 5\% to indicate significance.

\section{RESULTS AND DISCUSSION}

\section{Characterization of Carbohydrate Fermentation Profile of $P$. pentosaceus}

\section{7}

The carbohydrate fermentation profile of $P$. pentosaceus 147 indicated an ability to metabolize lactose. This result confirmed that the strain was able to use lactose as an energy source, pointing to the adequacy of $\mathrm{CW}$ as an alternative culture medium for growth and bacteriocin production.

\section{Antimicrobial Activity of $P$. pentosaceus 147 on MRS and Modified MRS}

The antimicrobial activity of $P$. pentosaceus 147 against L. monocytogenes 104 is shown in Figure 1. Non-significant differences in the growth of the bacteriocinogenic strain were found on tested culture media $(p=0.12)$. Comparing antimicrobial activity in MRS and modified MRS, a slight increase after $18 \mathrm{~h}$ of incubation was observed; nevertheless, non-significant differences were found $(p=0.33)$. Similar results have been reported for bacteriocin production by other Pediococcus spp. strains. Halami and Chandrashekar (2005) evaluated pediocin production of P. acidilactici C20 on whey broth supplemented with $2 \%$ of yeast extract and 0.1 of Tween ${ }^{\circledR} 80$, and compared this with MRS broth, a modified MRS and TGE (triptone-glucose-yeast extract) broth supplemented with 1 or $2 \%$ of lactose. P. acidilactici C20 showed a preference to metabolize $2 \%$ lactose as a carbon source on modified broth, and on whey supplemented with yeast extract as an additional source of nitrogen, the pediocin titer was $15,000 \mathrm{AU} / \mathrm{mL}$, which was very similar to the results of the present work (Halami and Chandrashekar, 2005). On the contrary, $P$. acidilactici $\mathrm{F}$ presented a decreased production of bacteriocin on a modified MRS broth supplemented with lactose compared to MRS. Nevertheless, in milk, the activity of $P$. acidilactici $\mathrm{F}$ was intermediate, most probably related to the protein components of milk, which can be useful for bacteriocin synthesis (Somkuti and Steinberg, 2010). Turgis et al. (2016) reported more efficient pediocin production by $P$. acidilactici MM33 with glucose as a carbohydrate source (Turgis et al., 2016). Additionally, pediocin production increased when the bacteriocinogenic strain $P$. pentosaceus NCDC273 was inoculated in a modified MRS broth that contained glucose instead of lactose at $20 \mathrm{~g} / \mathrm{L}$ (Vijay Simha et al., 2012). The results obtained in the present section showed that $P$. pentosaceus 147 is able to use lactose as carbon source and that the proteins and other components of the cheese whey

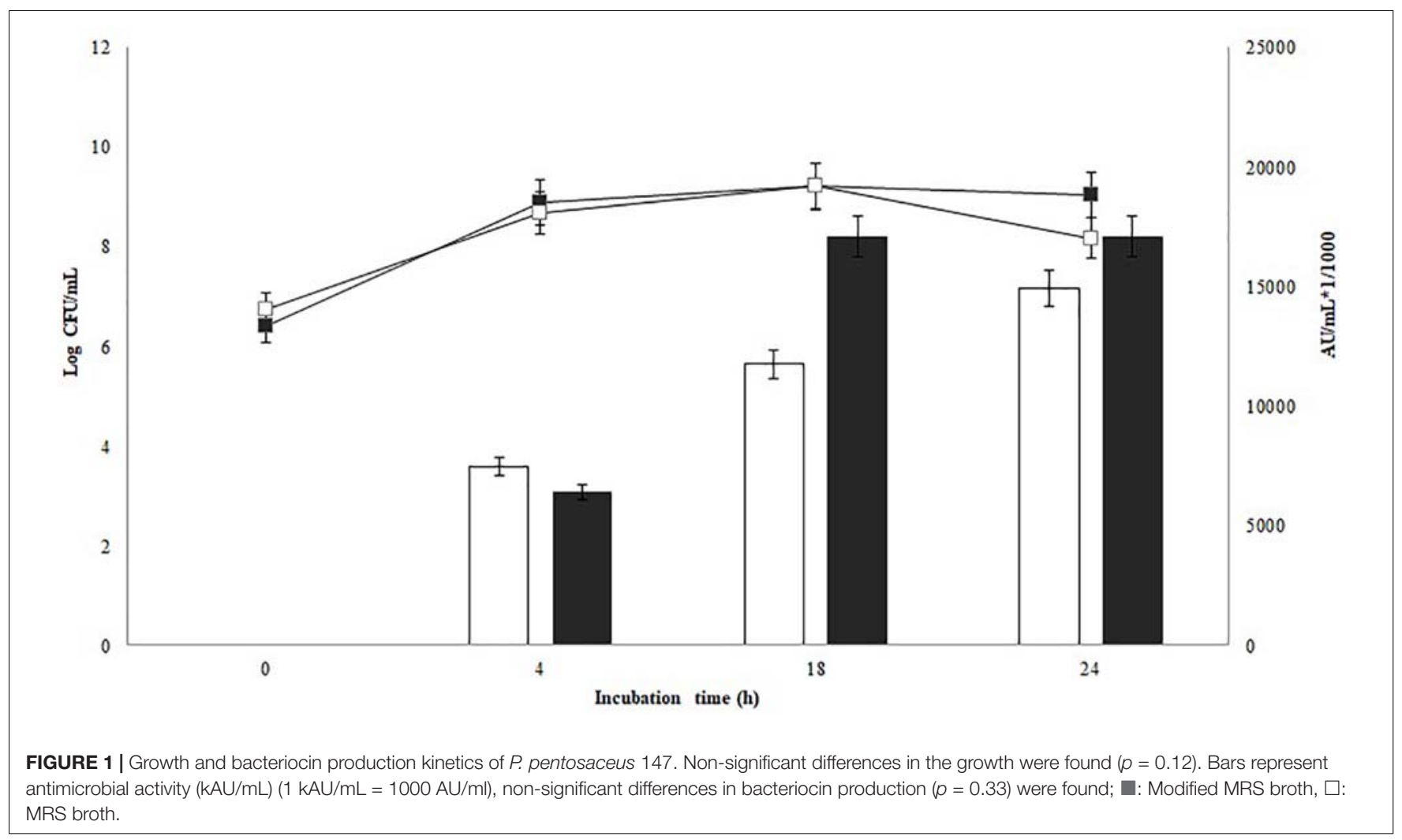



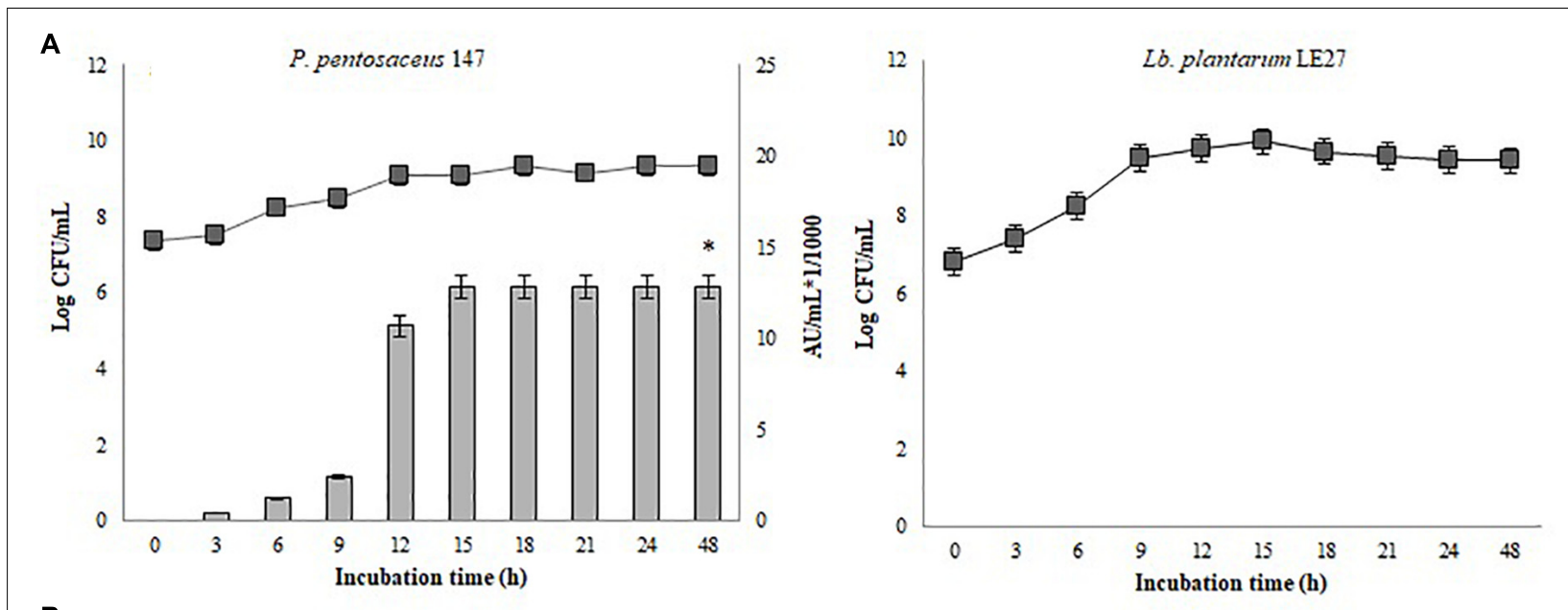

B
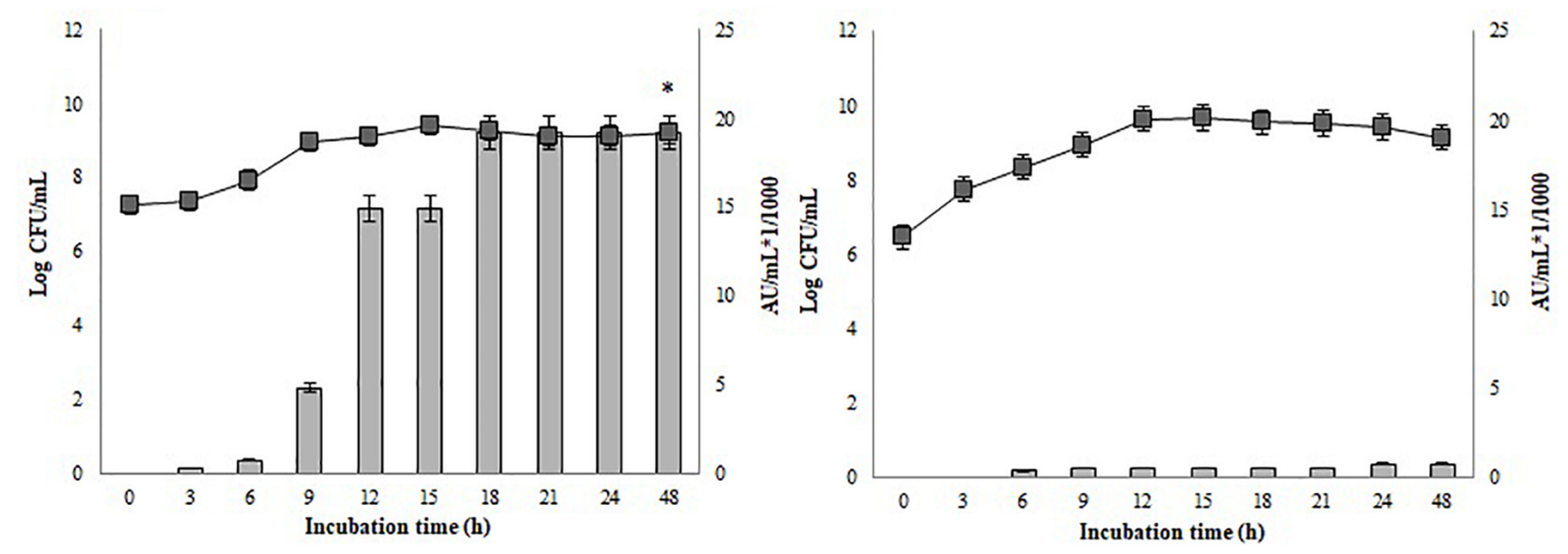

FIGURE 2 | Growth and bacteriocin production kinetics of $P$. pentosaceus 147 (left) and Lb. plantarum LE27 (right). (A) MRS broth, (B) CW broth; $\square$ : growth kinetic, non-significant differences in the growth of $P$. pentosaceus $147(p=0.08)$ and of $L$ b. plantarum LE27 $(p=1)$ were found; Bars represent antimicrobial activity $(\mathrm{kAU} / \mathrm{mL})(1 \mathrm{kAU} / \mathrm{mL}=1000 \mathrm{AU} / \mathrm{ml})$ of $P$. pentosaceus 147 , significant differences $\left(1.14 \mathrm{e}^{-08}\right)$ were found $(*)$.

can promote the production of bacteriocins, as evidenced in Figure 1.

\section{Growth Dynamics of Lb. plantarum LE27 and $P$. pentosaceus 147 Mono-Cultures in CW Broth}

Figure 2 shows the kinetic growth and bacteriocin production of $P$. pentosaceus 147 and Lb. plantarum LE27. Non-significant differences in the growth of $L b$. plantarum LE27 on MRS and CW broths were found $(p=1)$. Lb. plantarum LE27 exhibited antimicrobial activity at a concentration of $800 \mathrm{AU} / \mathrm{mL}$ against L. monocytogenes 104 when cultured in CW broth, while there was no antimicrobial activity in the MRS broth. That result suggests that CW can induce bacteriocin expression (Figure 2B, left). Non-significant differences in the growth of $P$. pentosaceus 147 in the MRS and CW broths were recorded $(p=0.8)$. Significant differences in antimicrobial activity $\left(1.14 \mathrm{e}^{-08}\right)$ in MRS and CW, and also using different biomass concentrations of $P$. pentosaceus 147 in the CW broth, were found $\left(p=2.23 \mathrm{e}^{-09}\right)$.
Figure 3 shows an antimicrobial activity of $19,200 \mathrm{AU} / \mathrm{mL}$ with an inoculum of $10^{6} \mathrm{CFU} / \mathrm{mL}$ ca. (final concentration) and of $12,800 \mathrm{AU} / \mathrm{mL}$ with $10^{5} \mathrm{CFU} / \mathrm{mL}$ ca. (final concentration) of inoculum.

Different studies have demonstrated that whey is an adequate substrate that supports the growth of Lactobacillus spp. strains as well as metabolite production, such as lactic acid (Panesar and Kennedy, 2011; Prazeres et al., 2012) or bacteriocins (Liu et al., 2005; Wolf-Hall et al., 2009; Garsa et al., 2014). Growth of $P$. pentosaceus 147 on the MRS and CW broths was very similar (Figure 2, right). Maximal antimicrobial activity on the MRS broth was $12,800 \mathrm{AU} / \mathrm{mL}$ while it was $19,200 \mathrm{AU} / \mathrm{mL}$ on the CW broth. Guerra et al. (2001) used concentrated and diluted whey in a culture of $P$. acidilactici NRRL B-5627, obtaining growth and bacteriocin production; the antimicrobial activity was higher than that obtained with Lactobacillus strains (Guerra et al., 2001), which was similar to the results of the present work. Although most Pediococcus spp. strains are not characterized for lactose fermentation (Papagianni and Anastasiadou, 2009), between $11 \%$ and $89 \%$ of Pediococcus strains are able to ferment 


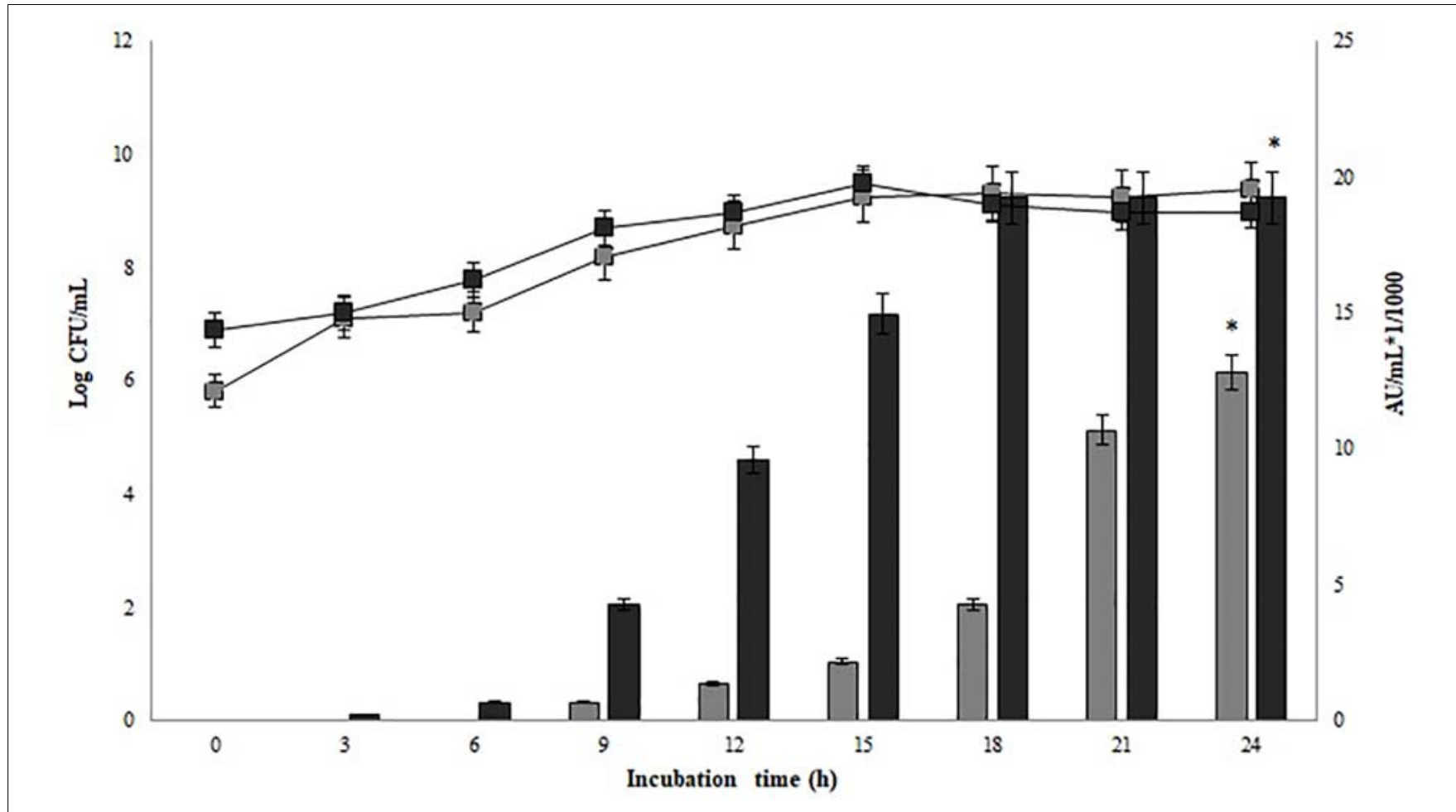

FIGURE 3 | Growth and bacteriocin production kinetics P. pentosaceus 147 on CW broth. Inocula concentrations; $\square: 10^{5} \mathrm{CFU} / \mathrm{mL}$, $\mathbf{\square}: 10^{6}$ UFC/mL. Bars represent antimicrobial activity $(\mathrm{kAU} / \mathrm{mL})(1 \mathrm{kAU} / \mathrm{mL}=1000 \mathrm{AU} / \mathrm{ml})$, significant differences in bacteriocin production of $P$. pentosaceus $147\left(p=2.23 \mathrm{e}^{-09}\right)$ were found $(*)$.

lactose (Vos et al., 2009). Considering that the growth kinetics of $P$. pentosaceus 147 on the MRS and CW broths did not present significant differences $(p=0.8)$, it is possible to confirm that cheese whey is a good complex nutrient source for supporting the growth of LAB strains, as previously reported (Chaves de Lima et al., 2017).

\section{Growth Dynamics and Bacteriocin Production of $P$. pentosaceus 147 and $L b$. plantarum LE27 Co-culture in CW Broth}

Significant differences in antimicrobial activity between the mono-culture of $P$. pentosaceus 147 and co-culture of $P$. pentosaceus 147 and Lb. plantarum LE27 were recorded $(p=0.003)$. As observed in Figure 4, the presence of Lb. plantarum LE27 (10 $\left.5^{5} \mathrm{CFU} / \mathrm{mL}\right)$ showed an increase from 19,200 $\mathrm{AU} / \mathrm{mL}$ (in mono-culture) to 51,200 $\mathrm{AU} / \mathrm{mL}$ (in co-culture) of bacteriocin production. Additionally, significant differences in antimicrobial activity, using $10^{5}$ and $10^{6} \mathrm{CFU} / \mathrm{mL}$ as an inoculum of the inductor strain $L b$. plantarum LE27, were found $(p=0.02)$. On the other hand, in both cases, significant differences in growth kinetics were observed $(p=0.002)$ for $P$. pentosaceus 147 and $\left(p=3.86 \mathrm{e}^{-5}\right)$ for $L b$. plantarum LE27.

The strain of $L b$. plantarum LE27 used in the present work as an inductor of bacteriocin production by $P$. pentosaceus 147 was reported as a bacteriocinogenic strain against some L. monocytogenes and E. faecalis strains (Amortegui et al., 2014). However, $L b$. plantarum LE27 did not present any antimicrobial activity against L. monocytogenes 104 on the MRS broth and only very low antimicrobial activity on CW. According to the results presented in Figure 2 (mono-culture), the activity of $P$. pentosaceus 147 was $19,200 \mathrm{AU} / \mathrm{mL}$, which shows a reduction from the initial titers obtained immediately after isolation (51,200 AU/mL) (Gutiérrez-Cortés et al., 2018).

As bacteriocin production by a producer strain is generally basal, if the cellular density is bigger in the lag and exponential phases of growth, the extracellular bacteriocin concentration can be higher (Brurberg et al., 1997; Tabasco et al., 2009). Similar results were reported with an inoculum of $10^{7} \mathrm{CFU} / \mathrm{mL}$ of Lb. plantarum LPCO10 in comparison to $10^{5} \mathrm{CFU} / \mathrm{mL}$ (LealSánchez et al., 2002). Abbasiliasi et al. (2016) performed an optimization of an inoculum of $P$. acidilactici Kp10 between 1 and $10 \%$ and found maximal activity with $3 \%$ of inoculum. Nevertheless, the authors concluded that inoculum size had less importance than $\mathrm{pH}$ or incubation temperature on bacteriocin production (Abbasiliasi et al., 2016). Similar results were also observed for Lb. acidophilus LF221 and Carnobacterium piscicola A9b (Himelbloom et al., 2001). However, Lc. lactis subsp. lactis ST1 showed maximal activity with $10^{5}$ inoculum and less activity with higher concentrations (Taheri et al., 2012). In the present work, the inoculum that generated the maximal antimicrobial activity $\left(10^{6} \mathrm{CFU} / \mathrm{mL}\right)$ in the co-culture was selected for further analysis.

In the mono-culture, $P$. pentosaceus 147 presented reduced antimicrobial activity and, in the case of $L b$. plantarum LE27, was undetectable. That behavior, presented after the 


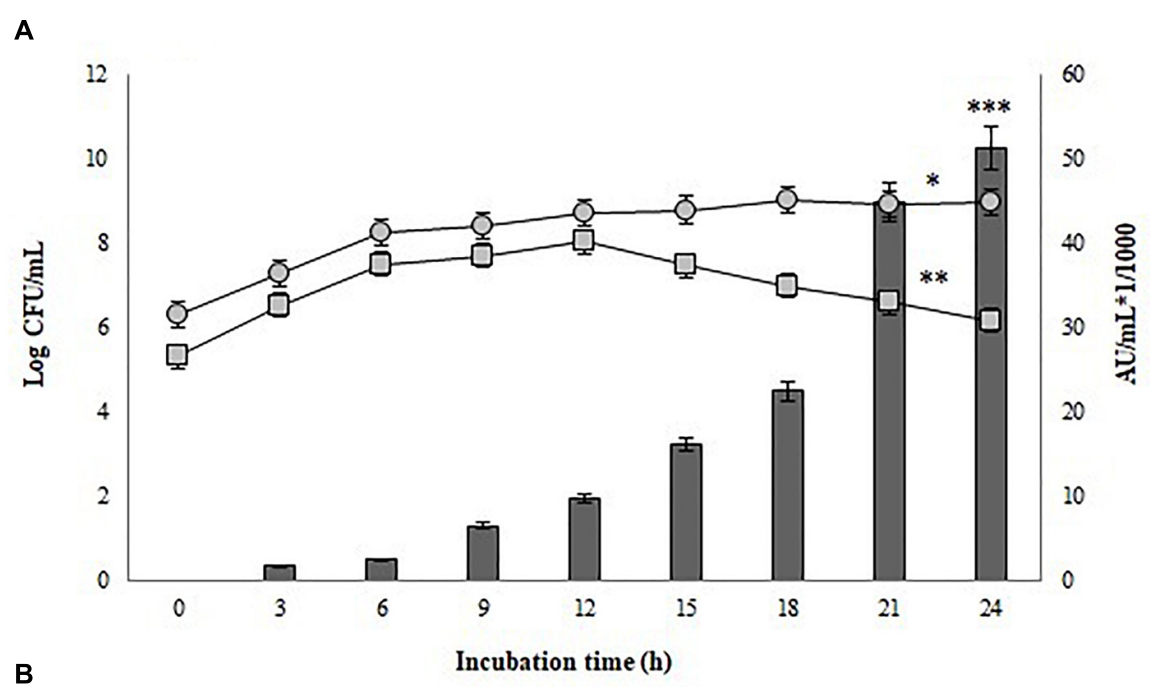

B

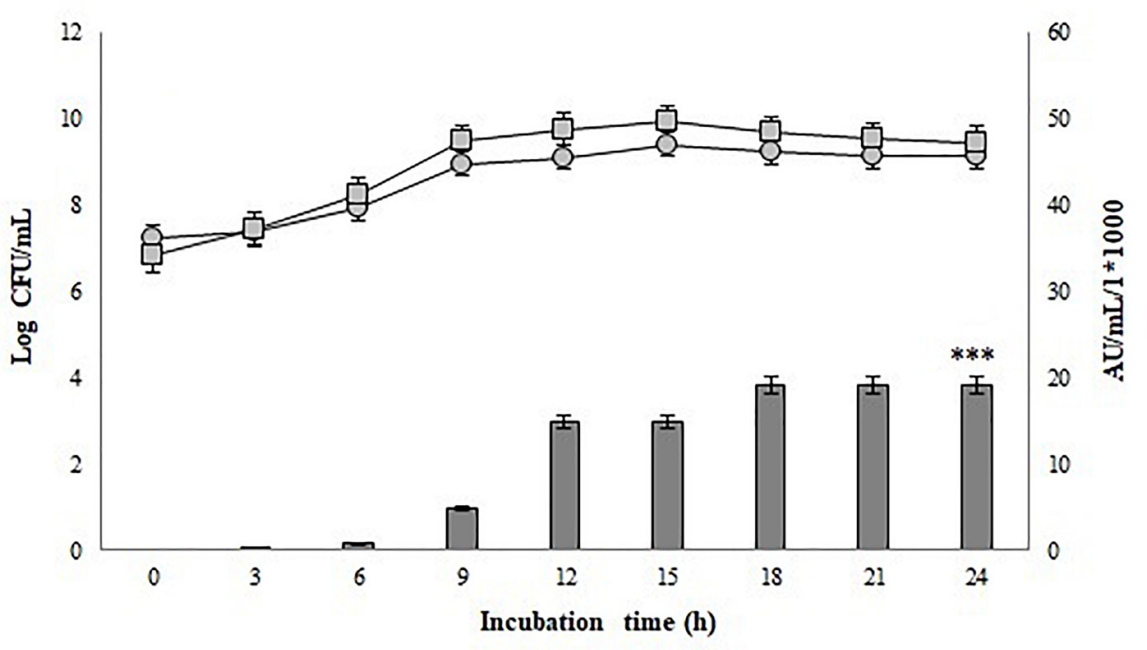

FIGURE 4 | Growth and bacteriocin production kinetics of co-culture in CW broth; •: P. pentosaceus 147, $\mathbf{\square}: L b$. plantarum LE27. (A) P. pentosaceus 147 and $L b$. plantarum LE27 co-culture, (B) Control in mono-culture in CW broth; $\bullet$ : Growth of $P$. pentosaceus 147, significant differences were found $(p=0.002)(*)$. $\square:$ Growth of $L b$. plantarum LE27, significant differences were found $\left(p=3.86^{-5}\right)\left({ }^{* *}\right)$. Bars represent antimicrobial activity $(\mathrm{kAU} / \mathrm{mL})(1 \mathrm{kAU} / \mathrm{mL}=1000 \mathrm{AU} / \mathrm{ml})$ of P. pentosaceus 147 , significant differences $(p=0.03)$ were found $(* * *)$.

TABLE 3 | Specific growth rate and antimicrobial activity of mono culture and co-culture.

\begin{tabular}{|c|c|c|c|c|c|c|c|c|}
\hline \multirow[b]{3}{*}{ Time (h) } & \multicolumn{4}{|c|}{ P. pentosaceus 147} & \multicolumn{4}{|c|}{ Lb. plantarum 147} \\
\hline & \multicolumn{2}{|c|}{ Mono-culture } & \multicolumn{2}{|c|}{ Co-culture } & \multicolumn{2}{|c|}{ Mono-culture } & \multicolumn{2}{|c|}{ Co-culture } \\
\hline & Log CFU & $\mathrm{AU} / \mathrm{mL}$ & Log CFU & $\mathrm{AU} / \mathrm{mL}$ & Log CFU* & $\mathrm{AU} / \mathrm{mL}$ & Log CFU* & $\mathrm{AU} / \mathrm{mL}$ \\
\hline & $7.24 \pm 0.32$ & $0 \pm 0.0$ & $6.27 \pm 0.33$ & $0 \pm 0.0$ & $6.46 \pm 0.06$ & $0 \pm 0.0$ & $5.3 \pm 0.43$ & - \\
\hline & $7.36 \pm 0.09$ & $266 \pm 0.14$ & $7.27 \pm 0.10$ & $1600 \pm 0.0$ & $7.74 \pm 0.089$ & $0 \pm 0.0$ & $6.5 \pm 0.86$ & - \\
\hline & $7.92 \pm 0.21$ & $733 \pm 0.05$ & $8.26 \pm 0.21$ & $2400 \pm 0.21$ & $8.35 \pm 0.25$ & $400 \pm 0.0$ & $7.49 \pm 0.58$ & - \\
\hline & $9.40 \pm 0.03$ & $14933 \pm 0.08$ & $8.78 \pm 0.03$ & $16000 \pm 0.12$ & $9.67 \pm 0.04$ & $533 \pm 0.14$ & $7.46 \pm 0.18$ & - \\
\hline & $9.24 \pm 0.11$ & $19200 \pm 0.0$ & $9.03 \pm 0.11$ & $22400 \pm 0.08$ & $9.56 \pm 0.11$ & $533 \pm 0.14$ & $6.98 \pm 0.98$ & - \\
\hline & $9.12 \pm 0.35$ & $19200 \pm 0.0$ & $8.93 \pm 0.04$ & $44800 \pm 0.08$ & $9.51 \pm 0.02$ & $800 \pm 0.0$ & $6.58 \pm 0.47$ & - \\
\hline & $9.13 \pm 0.01^{*}$ & $19200 \pm 0.0^{* *}$ & $8.96 \pm 0.14^{*}$ & $51200 \pm 0.0^{* *}$ & $9.42 \pm 0.05^{*}$ & $800 \pm 0.0$ & $6.14 \pm 0.14^{*}$ & - \\
\hline
\end{tabular}

*Significant differences in kinetics growth were found ( $p<0.05)$. ** Significant differences in bacteriocin production by $P$. pentosaceus 147 were found $(p<0.05)$. 

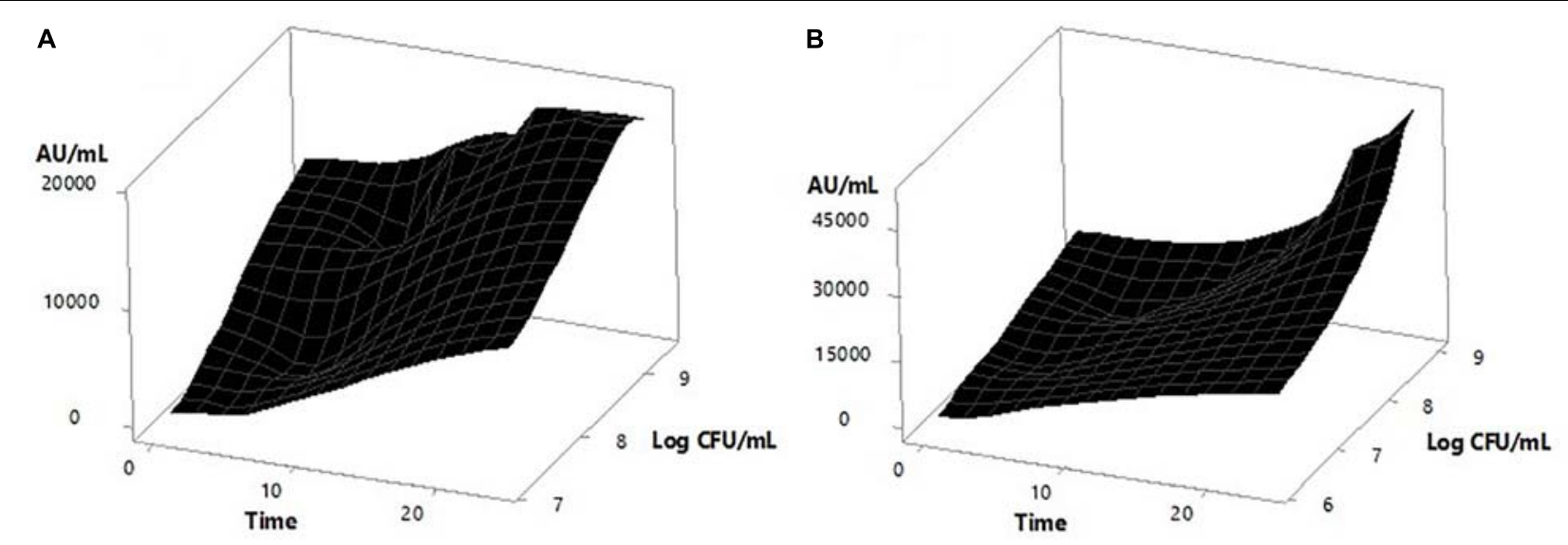

FIGURE 5 | Surface response graphs corresponding to $P$. pentosaceus 147 growths and antimicrobial activity during the incubation time. (A) Mono-culture and (B) Co-culture.

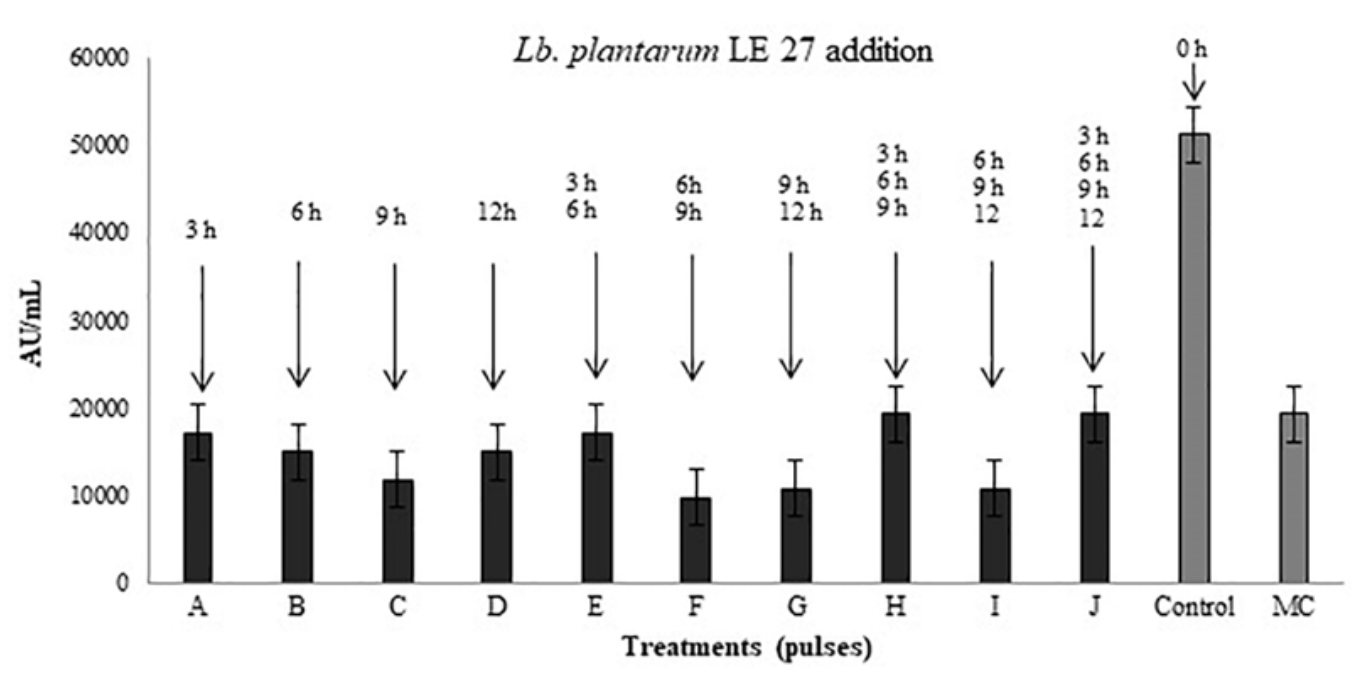

FIGURE 6 | Antimicrobial activity after addition of induction pulses of Lb. plantarum LE27 to P. pentosaceus 147 culture. A: 3 h; B: 6 h; C: 9 h; D: 12 h; E: 3 and 6 h; F: 6 and 9 h; G: 9 and 12 h; H: 3, 6, and 9 h; I: 6, 9, and 12 h; J: 3, 6, 9, and 12 h. Control: co-culture of P. pentosaceus 147 and Lb. plantarum LE27 inoculated at the same time (0 h). MC: P. pentosaceus 147 in mono-culture.

purification of strains from some microbial systems, could be explained by the absence of an inductor strain as a stimulus for the other strain to express some survival strategies, such as the production of antimicrobial substances in response to population density (Cornforth and Foster, 2013). Therefore, the antimicrobial activity of pure cultures decreases drastically in culture systems without competition. This behavior makes bacteriocin production an unstable trait of bacteria, being associated with the environment, and which tends to decrease and disappear under different laboratory conditions (Maldonado et al., 2004).

The aim of the present work was to increase bacteriocin production by the co-culture of $P$. pentosaceus 147, with Lb. plantarum LE27 as an inductor strain, since phylogenetic closeness generates the possibility that the sensor system of $P$. pentosaceus 147 could detect the extracellular signal peptides produced by $L b$. plantarum LE27 on the CW broth, as previously suggested (Chanos and Mygind, 2016). This kind of culture generates interactions between the two populations by establishing cell-to-cell interactions, similar to the natural competitive conditions in the environment (Goers et al., 2014).

For the pure culture of $P$. pentosaceus 147 in the CW broth, antimicrobial activity over L. monocytogenes 104 of CFS was $19,200 \mathrm{AU} / \mathrm{mL}$ (Figure 3). In the case of the co-culture of $P$. pentosaceus $147\left(10^{6} \mathrm{CFU} / \mathrm{mL}\right)$ and $L b$. plantarum LE27 $\left(10^{5}\right.$ $\mathrm{CFU} / \mathrm{mL}$ ) on the $\mathrm{CW}$ broth, the antimicrobial activity titer was 51,200 AU/mL (Figure 4). As observed in Figure 4, the presence of $\mathrm{Lb}$. plantarum LE27 $\left(10^{5} \mathrm{CFU} / \mathrm{mL}\right)$ determined a difference of $19,200 \mathrm{AU} / \mathrm{mL}$ (in pure culture) to $51,200 \mathrm{AU} / \mathrm{mL}$ (in co-culture) of bacteriocin production by $P$. pentosaceus 147 . These results can be linked to the QS mechanism, as reported in different studies 
(Maldonado et al., 2004; Chang et al., 2007; Straume et al., 2007; Man et al., 2012; Calasso et al., 2013; Maldonado-Barragán et al., 2013). The role of QS on bacteriocin production has been studied in more detail on $L b$. plantarum strains; the bacteriocinogenic $L b$. plantarum NC8 has been used in co-cultures with different genera of $\mathrm{LAB}$ as inducers due to the production of inductor peptides on the broth after incubation, and allowing the regulation of expression as a control of the synthesis of bacteriocin mediated by autoinductors (Maldonado et al., 2004).

Table 3 shows the specific growth rate and antimicrobial activity of both strains in mono and co-cultures. It was noticed that the final biomass presented differences in both cases. In the co-culture, the decrease in the Lb. plantarum LE 27 biomass was larger due the effect of the bacteriocins suspended in the medium. In Figure 4, growth kinetics show similar behaviors of $P$. pentosaceus 147 in mono- and co-culture. Nevertheless, significant differences were found $(p=0.02)$, therefore it is possible to conclude that in this case the co-culture had a negative effect on bacterial growth because of the small reduction that was observed. Mathys et al. (2009) reported no increase in the biomass of a co-cultured Bifidobacterium thermophilum RBL67 and P. acidilactici UVA1 (Mathys et al., 2009), and the same was also found for $L b$. plantarum DC400 co-cultured with L. plantarum DPPMA20 and Lb. sanfranciscensis DPPMA174 (Calasso et al., 2013). Contrasting results have been reported with the $L b$. plantarum KLDS1.0391 strain, where the biomass increased after co-culturing with different LAB strains due to the existence of a direct relation between biomass and antimicrobial activity (Man et al., 2012).

Rojo-Bezares et al. (2007) reported that no antimicrobial activity from $\mathrm{Lb}$. plantarum $\mathrm{J} 23$ was observed in a pure culture. Even so, after $6 \mathrm{~h}$ of co-culture with Lc. lactis MG1363 and Lb. hilgardii J8, the strain showed activity; the same authors also reported that contact with living inducer cells was necessary for the development of activity, and CFS or dead cells did not induce antimicrobial activity in Lb. plantarum J23 (Rojo-Bezares et al., 2007). The non-induction by the addition of CFS or dead cells has been explained by the fact that inductor molecules could not be released into the culture medium and, therefore, remained in the intracellular space or associated with the membrane, and could not be sensed by bacteriocinogenic cells (Chanos and Mygind, 2016). However, it has been demonstrated that in some cases, such as in the production of plantaricin PlnA by Lb. plantarum, cell-to-cell contact was not necessary to increase antimicrobial activity (Di Cagno et al., 2010). Different bacterial species are able to increase the bacteriocin production. Plantaricin production by Lb. plantarum KLDS1.0391 increased in the presence of different strains from genera Lactobacillus, Lactococcus, Leuconostoc, Streptococcus, and specially Enterococcus (Man et al., 2012). Another study used different strains of Lb. plantarum in coculture with LAB strains and found that Lc. lactis ssp. lactis IL1403 was the only one that was able to act as an inductor with all Lactobacillus spp. strains, suggesting that the ability of induction depends on the particular subspecies (Maldonado-Barragán et al., 2013).

Figure 4 also shows that the inducer strain apparently had some sensitivity to high concentrations of the peptide, since a decrease in biomass was observed after $15 \mathrm{~h}$ of incubation when the bacteriocin titer was $16,000 \mathrm{AU} / \mathrm{mL}$ with $10^{5} \mathrm{CFU} / \mathrm{mL}$ of inoculum, and after $18 \mathrm{~h}$ was $19,200 \mathrm{AU} / \mathrm{mL}$ with $10^{6}$ $\mathrm{CFU} / \mathrm{mL}$. However, the biomass reduction (which was significant $p=3.86 \mathrm{e}^{-5}$ ) was not high enough to stop metabolite production, obtaining a final activity of $51,200 \mathrm{AU} / \mathrm{mL}$ in the first case and $38,400 \mathrm{AU} / \mathrm{mL}$ in the second case. Figure 5 shows the surface response graph that represents the antimicrobial activity and biomass behavior during incubation. These results differ from those obtained by $L b$. plantarum $\mathrm{J} 23$ in co-culture with $L b$. hilgardii $\mathrm{J} 81$ which, being susceptible, disappeared in the medium, generating a decrease in bacteriocin production at the end of incubation (Rojo-Bezares et al., 2007). The pediocin produced by $P$. pentosaceus 147 corresponds to the fragment of 1,044 bp (Gutiérrez-Cortés et al., 2018), reported as pediocin PA-1/AcH (Marugg et al., 1992); according to this theory, its expression is regulated by QS. As a consequence, the present work has demonstrated that it is possible to obtain higher expression of the bacteriocin by $P$. pentosaceus 147 by the presence of an inducer, in this case Lb. plantarum $\mathrm{J} 23$.

\section{Addition of Lb. plantarum LE27 at Different Times as Pulses of Induction in the Bacteriocin Production by $P$. pentosaceus 147}

Figure 6 shows the antimicrobial activity of $P$. pentosaceus 147 co-inoculated with $L b$. plantarum LE27 at different times and frequencies. The treatment that produced the highest titer of bacteriocins of 51,200 AU/mL was the control, which means that the optimal moment to add the inducer strain is at the same time the inoculation of the producer strain starts the co-culture incubation.

Figure 6 also shows that in treatments where the induction begins after $6 \mathrm{~h}$ of incubation (treatments C, F, G, I), $P$. pentosaceus 147 presented the lowest antimicrobial activity compared to the bacteriocin production in the pure culture. Similar results have been reported with the bacteriocinogenic strains Lb. helveticus M92, Lb. plantarum L4 and E. faecium L3, which were inoculated with the inducer strain Lc. lactis subsp. lactis LMG 9450, at the same time obtaining an increment in antimicrobial activity (Kos et al., 2011). The same occurred when $L b$. plantarum $\mathrm{NC} 8$ was cultured at the same time with $L c$. lactis MG1363 (Maldonado et al., 2004), and when Lb. salivarius, E. durans, E. faecium, E. hirae, and E. faecium were cultured at the same time with $L b$. crispatus NRRL and Lb. acidophilus as inducers (Svetoch et al., 2010).

\section{CONCLUSION}

The co-culturing of LAB has proven to be an alternative for the induction of bacteriocin production. In the case of $P$. pentosaceus 147 , it has been shown that the presence of $L b$. plantarum LE27 generates an increase in the production of pediocin, as evidenced in the antimicrobial activity against $L$. monocytogenes 104. This allows for the application of this type of induction 
as an alternative for research into the large-scale production of bacteriocin for industrial purposes. Additionally, in this study, it was shown that cheese whey can be considered as a promoter substrate for the expression of bacteriocins since an increase was observed with respect to activity in the MRS broth. In the present work, different induction times were evaluated, finding greater effectiveness when the inoculation of the two strains was performed at the same time. These results are at an initial phase of the research into the induction mechanisms, and must be followed by an understanding at the proteomic level of what occurs with the expression of genes related to the stimulation of pediocin synthesis by $P$. pentosaceus 147 in co-culture.

\section{AUTHOR CONTRIBUTIONS}

CG-C, HS, and GB conceived the idea. HS and GB directed the project. CG-C and ST carried out the experiments and drafted

\section{REFERENCES}

Abbasiliasi, S., Tan, J. S., Kadkhodaei, S., Nelofer, R., Tengku Ibrahim, T. A., Mustafa, S., et al. (2016). Enhancement of blis production by pediococcus acidilactici kp10 in optimized fermentation conditions using an artificial neural network. RSC Adv. 6, 6342-6349. doi: 10.1039/C5RA22879D

Amortegui, J., Rodríguez-López, A., Rodríguez, D., Carrascal, A. K., AlmécigaDíaz, C. J., Melendez, A. D. P., et al. (2014). Characterization of a new bacteriocin from Lactobacillus plantarum Le5 and Le27 isolated from ensiled corn. Appl. Biochem. Biotechnol. 172, 3374-3389. doi: 10.1007/s12010-0140757-x

Bader, J., Mast-Gerlach, E., Popović, M. K., Bajpai, R., and Stahl, U. (2010). Relevance of microbial coculture fermentations in biotechnology. J. Appl. Microbiol. 109, 371-387. doi: 10.1111/j.1365-2672.2009.04659.x

Beshkova, D., and Frengova, G. (2012). Bacteriocins from lactic acid bacteria: microorganisms of potential biotechnological importance for the dairy industry. Eng. Life Sci. 12, 419-432. doi: 10.1002/elsc.201100127

Brauman, A., Keleke, S., Malonga, M., Miambi, E., and Ampe, F. (1996). Microbiological and biochemical characterization of cassava retting, a traditional lactic acid fermentation for foo-foo (cassava flour) production. Appl. Environ. Microbiol. 62, 2854-2858.

Brurberg, M. B., Nes, I. F., and Eijsink, V. G. (1997). Pheromone-induced production of antimicrobial peptides in Lactobacillus. Mol. Microbiol. 26, 347360. doi: 10.1046/j.1365-2958.1997.5821951.x

Calasso, M., Di Cagno, R., De Angelis, M., Campanella, D., Minervini, F., and Gobbetti, M. (2013). Effects of the peptide pheromone plantaricin a and cocultivation with Lactobacillus sanfranciscensis Dppma174 on the exoproteome and the adhesion capacity of Lactobacillus plantarum Dc400. Appl. Environ. Microbiol. 79, 2657-2669. doi: 10.1128/aem.03625-12

Chang, J. Y., Lee, H. J., and Chang, H. C. (2007). Identification of the agent from Lactobacillus plantarum Kfri464 that enhances bacteriocin production by Leuconostoc citreum Gj7. J. Appl. Microbiol. 103, 2504-2515. doi: 11.1111/ j.1365-2672.2007.03543.x

Chanos, P., and Mygind, T. (2016). Co-culture-inducible bacteriocin production in lactic acid bacteria. Appl. Microbiol. Biotechnol. 100, 4297-4308. doi: 10.1007/ s00253-016-7486-8

Chaves de Lima, E. D. L., de Moura Fernandes, J., and Cardarelli, H. R. (2017). Optimized fermentation of goat cheese whey with Lactococcus lactis for production of antilisterial bacteriocin-like substances. $L W T-$ Food Sci. Technol. 84, 710-716. doi: 10.1016/j.lwt.2017.06.040

Chiarini, E. (2007). Listeria Monocytogenes Em Matadouros De Aves: Marcadores Serologicosegeneticos No Monitoramento Desua Disseminacao. Ph.D thesis, University of São Paulo, Sao Paulo. the manuscript. LN verified the experimental methods. HS, GB, and $\mathrm{LN}$ revised and approved the final manuscript.

\section{FUNDING}

COLCIENCIAS (Departamento Administrativo de Ciencia, Tecnología e Innovación - Colombia) Grant 567, Coordenação de Aperfeiçoamento de Pessoal de Nível Superior (CAPES Brazil), and the Conselho Nacional de Desenvolvimento Científico e Tecnológico (CNPq - Brazil). FAPEMIG (Fundação de Amparo à Pesquisa de MG).

\section{ACKNOWLEDGMENTS}

Institute for the Study of Inborn Errors of Metabolism, School of Sciences, Pontificia Universidad Javeriana, Bogotá, Colombia.

Conti, J. P., Ceriani, M. C., Juliarena, M. A., and Esteban, E. N. (2012). Perfil proteico Y peptídico de una base fluida para bebidas funcionales obtenida por fermentación de lactosuero. Inform. Tecnol. 23, 61-70. doi: 10.4067/S071807642012000200008

Cornforth, D. M., and Foster, K. R. (2013). Competition sensing: the social side of bacterial stress responses. Nat. Rev. Microbiol. 11, 285-293. doi: 10.1038/ nrmicro2977

De Arauz, L. J., Jozala, A. F., Baruque-Ramos, J., Mazzola, P. G., Júnior, A. P., and Penna, T. C. V. (2012). Culture medium of diluted skimmed milk for the production of nisin in batch cultivations. Ann. Microbiol. 62, 419-426. doi: 10.1007/s13213-011-0278-6

Di Cagno, R., De Angelis, M., Calasso, M., Vincentini, O., Vernocchi, P., Ndagijimana, M., et al. (2010). Quorum sensing in sourdough Lactobacillus plantarum dc400: induction of plantaricin a (plna) under co-cultivation with other lactic acid bacteria and effect of plna on bacterial and caco-2 cells. Proteomics 10, 2175-2190. doi: 10.1002/pmic.200900565

Diep, D. B., Havarstein, L. S., and Nes, I. F. (1996). Characterization of the locus responsible for the bacteriocin production in Lactobacillus plantarum C11. J. Bacteriol. 178, 4472-4483. doi: 10.1128/jb.178.15.4472-4483.1996

Garsa, A. K., Kumariya, R., Kumar, A., Lather, P., Kapila, S., and Sood, S. K. (2014). Industrial cheese whey utilization for enhanced production of purified pediocin pa-1. LWT - Food Sci. Technol. 59, 656-665. doi: 10.1016/j.lwt.2014.07.008

Goers, L., Freemont, P., and Polizzi, K. M. (2014). Co-culture systems and technologies: taking synthetic biology to the next level. J. R. Soc. Interface 11:20140065. doi: 10.1098/rsif.2014.0065

Guerra, N. P., Rua, M. L., and Pastrana, L. (2001). Nutritional factors affecting the production of two bacteriocins from lactic acid bacteria on whey. Int. J. Food Microbiol. 70, 267-281. doi: 10.1016/S0168-1605(01)00551-7

Gutiérrez-Cortés, C., Suarez, H., Buitrago, G., Nero, L. A., and Todorov, S. D. (2018). Characterization of bacteriocins produced by strains of Pediococcus pentosaceus isolated from Minas cheese. Ann. Microbiol. 68, 383-398. doi: 10. 1007/s13213-018-1345-z

Halami, P. M., and Chandrashekar, A. (2005). Enhanced production of pediocin C20 by a native strain of Pediococcus acidilactici C20 in an optimized food-grade medium. Process. Biochem. 40, 1835-1840. doi: 10.1016/j.procbio.2004.06.065

Hati, S., Patel, N., Sakure, A., and Mandal, S. (2017). Influence of whey protein concentrate on the production of antibacterial peptides derived from fermented milk by lactic acid bacteria. Int. J. Peptide Res. Therap. 24, 87-98. doi: 10.1007/ s10989-017-9596-2

Himelbloom, B., Nilsson, L., and Gram, L. (2001). Factors affecting production of an antilisterial bacteriocin by carnobacterium piscicola strain A9B in laboratory media and model fish systems. J. Appl. Microbiol. 91, 506-513. doi: 10.1046/j. 1365-2672.2001.01401.x 
Jia, F.-F., Pang, X.-H., Zhu, D.-Q., Zhu, Z.-T., Sun, S.-R., and Meng, X.-C. (2017). Role of the luxs gene in bacteriocin biosynthesis by Lactobacillus plantarum Klds1.0391: a proteomic analysis. Sci. Rep. 7:13871. doi: 10.1038/s41598-01713231- 4

Kaur, B., Garg, N., and Sachdev, A. (2013). Optimization of bacteriocin production in Pediococcus acidilactici Ba28 using response surface methodology. Asian J. Pharm. Clin. Res. 6(Suppl. 1), 192-195.

Komnatnyy, V. V., Chiang, W. C., Tolker-Nielsen, T., Givskov, M., and Nielsen, T. E. (2014). Bacteria-triggered release of antimicrobial agents. Angew. Chem. (Int. Edn. Engl.) 53, 439-441. doi: 10.1002/anie.201307975

Kos, B., Beganović, J., Jurašić, L., Švadumović, M., Leboš Pavunc, A., Uroić, K., et al. (2011). Coculture-inducible bacteriocin biosynthesis of different probiotic strains by dairy starter culture Lactococcus lactis. Mljekarstvo 61, 273-282.

Kumar, M., Jain, A., Ghosh, M., and Ganguli, A. (2012). Industrial whey utilization as a medium supplement for biphasic growth and bacteriocin production by probiotic Lactobacillus casei La-1. Probiot. Antimicrob. Prot. 4, 198-207. doi: 10.1007/s12602-012-9104-0

Leal-Sánchez, M. V., Jiménez-Díaz, R., Maldonado-Barragán, A., GarridoFernández, A., and Ruiz-Barba, J. L. (2002). Optimization of bacteriocin production by batch fermentation of Lactobacillus plantarum Lpco10. Appl. Environ. Microbiol. 68, 4465-4471. doi: 10.1128/aem.68.9.4465-4471.2002

Liu, X., Chung, Y.-K., Yang, S.-T., and Yousef, A. E. (2005). Continuous nisin production in laboratory media and whey permeate by immobilized Lactococcus lactis. Process. Biochem. 40, 13-24. doi: 10.1016/j.procbio.2003.11.032

Maldonado, A., Ruiz-Barba, J. L., and Jiménez-Díaz, R. (2003). Purification and genetic characterization of plantaricin Nc8, a novel coculture-inducible two-peptide bacteriocin from Lactobacillus plantarum Nc8. Appl. Environ. Microbiol. 69, 383-389. doi: 10.1128/aem.69.1.383-389.2003

Maldonado, A., Ruiz-Barba, J. L., and Jiménez-Díaz, R. (2004). Production of plantaricin $\mathrm{Nc} 8$ by Lactobacillus plantarum Nc8 is induced in the presence of different types of gram-positive bacteria. Arch. Microbiol. 181, 8-16. doi: 10.1007/s00203-003-0606-8

Maldonado-Barragán, A., Caballero-Guerrero, B., Lucena-Padrós, H., and RuizBarba, J. L. (2013). Induction of bacteriocin production by coculture is widespread among plantaricin-producing Lactobacillus plantarum strains with different regulatory operons. Food Microbiol. 33, 40-47. doi: 10.1016/j.fm.2012. 08.009

Maldonado-Barragán, A., Caballero-Guerrero, B., Martín, V., Ruiz-Barba, J. L., and Rodríguez, J. M. (2016). Purification and genetic characterization of gassericin E, a novel co-culture inducible bacteriocin from Lactobacillus gasseri Ev1461 isolated from the vagina of a healthy woman. BMC Microbiol. 16:37. doi: 10 . 1186/s12866-016-0663-1

Man, L. L., Meng, X. C., and Zhao, R. H. (2012). Induction of plantaricin Mg under co-culture with certain lactic acid bacterial strains and identification of luxs mediated quorum sensing system in Lactobacillus plantarum Klds1.0391. Food Control 23, 462-469. doi: 10.1016/j.foodcont.2011.08.015

Marugg, J. D., Gonzalez, C. F., Kunka, B. S., Ledeboer, A. M., Pucci, M. J., Toonen, M. Y., et al. (1992). Cloning, expression, and nucleotide sequence of genes involved in production of pediocin $\mathrm{Pa}-1$, and bacteriocin from Pediococcus acidilactici Pac1.0. Appl. Environ. Microbiol. 58, 2360-2367.

Mathys, S., Meile, L., and Lacroix, C. (2009). Co-cultivation of a bacteriocinproducing mixed culture of Bifidobacterium thermophilum Rbl67 and pediococcus acidilactici Uval isolated from baby faeces. J. Appl. Microbiol. 107, 36-46. doi: 10.1111/j.1365-2672.2009.04186.x

Mesa-Pereira, B., O’Connor, P. M., Rea, M. C., Cotter, P. D., Hill, C., and Ross, R. P. (2017). Controlled functional expression of the Bacteriocins pediocin $\mathrm{Pa}-1$ and bactofencin a in Escherichia Coli. Sci. Rep. 7:3069. doi: 10.1038/s41598-01702868-w

Ng, W. L., and Bassler, B. L. (2009). Bacterial quorum-sensing network architectures. Ann. Rev. Genet. 43, 197-222. doi: 10.1146/annurev-genet102108-134304

Oppegard, C., Fimland, G., Anonsen, J. H., and Nissen-Meyer, J. (2015). The pediocin $\mathrm{Pa}-1$ accessory protein ensures correct disulfide bond formation in the antimicrobial peptide pediocin pa-1. Biochemistry 54, 2967-2974. doi: 10.1021/ acs.biochem.5b00164

Panesar, P. S., and Kennedy, J. F. (2011). Biotechnological approaches for the value addition of whey. Crit. Rev. Biotechnol. 32, 327-348. doi: 10.3109/07388551. 2011.640624
Papagianni, M., and Anastasiadou, S. (2009). Pediocins: the bacteriocins of pediococci. sources, production, properties and applications. Microb. Cell Fact. 8:3. doi: 10.1186/1475-2859-8-3

Pereira, C. S., Thompson, J. A., and Xavier, K. B. (2013). Ai-2-mediated signalling in bacteria. FEMS Microbiol. Rev. 37, 156-181. doi: 10.1111/j.1574-6976.2012. 00345.x

Prazeres, A. R., Carvalho, F., and Rivas, J. (2012). Cheese whey management: a review. J. Environ. Manage. 110, 48-68. doi: 10.1016/j.jenvman.2012.05.018

R Core Team (2015). R: A Language and Environment for Statistical Computing. Vienna: R Foundation for Statistical Computing. Available at: http://www.Rproject.org/

Rojo-Bezares, B., Sáenz, Y., Navarro, L., Zarazaga, M., Ruiz-Larrea, F., and Torres, C. (2007). Coculture-inducible bacteriocin activity of Lactobacillus plantarum strain J23 isolated from grape must. Food Microbiol. 24, 482-491. doi: 10.1016/j.fm.2006.09.003

Sánchez, G., Gil, M., Gil, M., Giraldo, F., Millán, L., and Villada, M. (2009). Aprovechamiento del suero lácteo de una empresa del norte antioquño mediante microorganismos eficientes. Produc. Más Lim. 4, 65-74.

Somkuti, G. A., and Steinberg, D. H. (2010). Pediocin production in milk by pediococcus acidilactici in co-culture with Streptococcus thermophilus and Lactobacillus delbrueckii subsp, Bulgaricus. J. Ind. Microbiol. Biotechnol. 37, 65-69. doi: 10.1007/s10295-009-0648-2

Sridevi, V., Yasarapu, N. S., Kancharana, S., Silarapu, S., Yerri, N. A., and Garapati, H. R. (2017). Optimized production of bacteriocin from cheaper carbon and nitrogen sources using response surface methodology. Res. J. Microbiol. 12, 42-49. doi: 10.3923/jm.2017.42.49

Straume, D., Kjos, M., Nes, I. F., and Diep, D. B. (2007). Quorum-sensing based bacteriocin production is down-regulated by N-terminally truncated species of gene activators. Mol. Genet. Genomics 278, 283-293. doi: 10.1007/s00438-0070251-z

Suganthi, V., and Mohanasrinivasan, V. (2015). Optimization studies for enhanced bacteriocin production by Pediococcus pentosaceus Kc692718 using response surface methodology. J. Food Sci. Technol. 52, 3773-3783. doi: 10.1007/s13197014-1440-5

Svetoch, E. A., Eruslanov, B. V., Perelygin, V. V., Levchuk, V. P., Seal, B. S., and Stern, N. J. (2010). Inducer bacteria, unique signal peptides, and lownutrient media stimulate in vitro bacteriocin production by Lactobacillus spp. and Enterococcus spp. strains. J. Agric. Food Chem. 58, 6033-6038. doi: 10.1021/ jf902802z

Tabasco, R., García-Cayuela, T., Peláez, C., and Requena, T. (2009). Lactobacillus acidophilus La-5 increases lactacin B production when it senses live target bacteria. Int. J. Food Microbiol. 132, 109-116. doi: 10.1016/j.ijfoodmicro.2009. 04.004

Taheri, P., Samadi, N., Ehsani, M. R., Khoshayand, M. R., and Jamalifar, H. (2012). An evaluation and partial characterization of a bacteriocin produced by Lactococcus lactis subsp lactis St1 isolated from goat milk. Braz. J. Microbiol. 43, 1452-1462. doi: 10.1590/s1517-838220120004000029

Taniguchi, M., and Tanaka, T. (2004). Clarification of interactions among microorganisms and development of co-culture system for production of useful substances. Adv. Biochem. Eng. Biotechnol. 90, 35-62. doi: 10.1007/b9 4191

Todorov, S. D., and Dicks, L. M. T. (2004). Effect of medium components on bacteriocin production by Lactobacillus pentosus St151br, a strain isolated from beer produced by the fermentation of maize, barley and soy flour. World J. Microbiol. Biotechnol. 20, 643-650. doi: 10.1023/B:WIBI.0000043196.09610.de

Todorov, S. D., and Dicks, L. M. T. (2006a). Effect of medium components on bacteriocin production by Lactobacillus plantarum strains St23ld and St341ld, isolated from spoiled olive brine. Microbiol. Res. 161, 102-108. doi: 10.1016/j. micres.2005.06.006

Todorov, S. D., and Dicks, L. M. T. (2006b). Medium components effecting bacteriocin production by two strains of Lactobacillus plantarum St414bz and St664bz isolated from boza. Biologia 61, 269-274. doi: 10.2478/s11756-0060049-1

Turgis, M., Vu, K. D., Millette, M., Dupont, C., and Lacroix, M. (2016). Influence of environmental factors on bacteriocin production by human isolates of Lactococcus lactis $\mathrm{Mm} 19$ and Pediococcus acidilactici Mm33. Probiot. Antimicrob. Proteins 8, 53-59. doi: 10.1007/s12602-0159204-8 
Vijay Simha, B., Sood, S. K., Kumariya, R., and Garsa, A. K. (2012). Simple and rapid purification of pediocin Pa-1 from Pediococcus pentosaceous Ncdc 273 suitable for industrial application. Microbiol. Res. 167, 544-549. doi: 10.1016/ j.micres.2012.01.001

Vos, P., Garrity, G., Jones, D., Krieg, N. R., Ludwig, W., Rainey, F. A., et al. (2009). Bergey's Manual of Systematic Bacteriology: The Firmicutes, vol. 3. New York, NY: Springer.

Williams, P., and Cámara, M. (2009). Quorum sensing and environmental adaptation in Pseudomonas aeruginosa: a tale of regulatory networks and multifunctional signal molecules. Curr. Opin. Microbiol. 12, 182-191. doi: 10. 1016/j.mib.2009.01.005

Wolf-Hall, C., Gibbons, W., and Bauer, N. (2009). Development of a lowcost medium for production of nisin from Lactococcus lactis subsp, lactis. World J. Microbiol. Biotechnol. 25, 2013-2019. doi: 10.1007/s11274-0090102-7
Zacharof, M. P., and Lovitt, R. W. (2012). Bacteriocins produced by lactic acid bacteria a review article. APCBEE Proc. 2, 50-56. doi: 10.1016/j.apcbee.2012. 06.010

Conflict of Interest Statement: The authors declare that the research was conducted in the absence of any commercial or financial relationships that could be construed as a potential conflict of interest.

Copyright (c) 2018 Gutiérrez-Cortés, Suarez, Buitrago, Nero and Todorov. This is an open-access article distributed under the terms of the Creative Commons Attribution License (CC BY). The use, distribution or reproduction in other forums is permitted, provided the original author(s) and the copyright owner(s) are credited and that the original publication in this journal is cited, in accordance with accepted academic practice. No use, distribution or reproduction is permitted which does not comply with these terms. 